\title{
PENGARUH PRICE EARNING RATIO, EARNING PER SHARE, RETURN ON EQUITY, DEBT TO EQUITY RATIO DAN NET PROFIT MARGIN TERHADAP RETURN SAHAM
}

(Pada Sektor Property and Real Estate Yang Terdaftar Di Bursa Efek Indonesia Periode 2013-2017)

\author{
${ }^{1)}$ Mohamad Zulman Hakim \\ Program Studi Akuntansi, Fakultas Ekonomi dan Bisnis \\ Universitas Muhammadiyah Tangerang \\ 1) zulman.hakim@umt.ac.id \\ ${ }^{2)}$ Dirvi Surya Abbas \\ Program Studi Akuntansi, Fakultas Ekonomi dan Bisnis \\ Universitas Muhammadiyah Tangerang \\ 2)abbas.dirvi@gmail.com
}

The purpose of this study was to determine the extent of the effect of price earnings ratio, earnings per share, return on equity, debt to equity ratio and net profit margin on stock returns. Price earning ratio is measured by the price per share divided by net income per share, earning per share is measured by net income after tax divided by the number of shares outstanding, as well as return on equity measured by net profit after tax divided by shareholders' equity multiplied by $100 \%$, the debt to equity ratio is measured by total debt divided by total equity and net profit margin is measured by net income after tax divided by net sales income. The stock return as the dependent variable is measured by the closing price of the current year minus the closing price of the previous year's share and then divided by the closing price of the previous year.

This study uses a sample of property and real estate subsector companies during 2013 - 2017 using purposive sampling method. The data used is obtained from annual reports listed on the Indonesia Stock Exchange. There were 17 companies during 20132017 that met the criteria. The analytical method used in this study is panel data regression analysis.

The results of this study indicate that price earnings ratio, earnings per share, debt to equity ratio and net profit margin have no significant effect on stock returns. While return on equity has a significant positive effect on stock returns.

Keywords: Price Earning Ratio, Earning per Share, Return on Equity, Debt to Equity Ratio, Net Profit Margin and Return Saham

\section{PENDAHULUAN}

Pasar modal memiliki peran penting bagi perekonomian suatu negara karena pasar modal menjalankan dua fungsi, yaitu pertama sebagai sarana bagi pendanaan usaha atau sebagai sarana bagi perusahaan untuk mendapatkan dana bagi masyarakat pemodal (investor). Kedua, pasar modal menjadi sarana bagi masyarakat untuk berinvestasi pada instrumen keuangan, seperti saham, obligasi, rekasadana, dan lain-lain 
(Martalena dan Malinda, 2011: 2). Dengan adanya pasar modal, investor sebagai pihak yang memiliki kelebihan dana dapat menginvestasikan dananya dalam sekuritas yang ada di pasar modal dengan harapan akan mendapatkan keuntungan. Sedangkan untuk perusahaan sebagai pihak yang memerlukan dana dapat memanfaatkan dana tersebut untuk mengembangkan kegiatan aktivitas operasional perusahaan, sehingga dapat meningkatkan kegiatan perekonomian negara dan kesejahteraan masyarakat luas.

Investor yang memilih berinvestasi dalam bentuk saham berarti berinvestasi dalam prospek perusahaan tersebut. Perusahaan yang tergabung dalam pasar modal harus mampu meningkatkan nilai perusahaannya karena nilai perusahaan yang tinggi tentu memberikan gambaran yang baik dan peluang returnyang besar. Apabila perusahaan menganggap semua investor adalah investor yang rasional makan dengan returnekspektasi yang tinggi tentu saja akan semakin banyak investor yang tertarik untuk membeli sekuritas yang dikeluarkan oleh perusahaan emiten sehingga tujuan pendanaan yang diinginkan perusahaan melalui pasar modal juga terpenuhi.

Menurut Sillaban (2007), setiap investor di pasar modal dituntut melakukan perencanaan yang efektif, yang didasari pengoptimalan keseimbangan antara risiko dan jumlah returnyang diharapkan. Dengan kata lain, investor bersedia menerima returnyang maksimal dengan suatu resiko tertentu atau memperoleh suatu returntertentu dengan resiko minimal. Pada dasarnya nilai return dari setiap sekuritas berbeda-beda satu sama lainnya. Tidak semua sekuritas akan memberikan returnyang sama bagi para investor. Returndari suatu sekuritas ditentukan oleh banyak hal seperti kinerja perusahaan dan strategi perusahaan mengelola laba yang dimiliki. Perusahaan dianggap gagal keuangannya jika perusahaan tersebut tidak mampu membayar kewajibannya pada waktu jatuh tempo meskipun total aktiva melebihi total kewajibannya pada waktu jatuh tempo.

Seorang investor melakukan berbagai cara agar dapat mendapatkan return sesuai dengan yang diinginkan, dengan melakukan analisis sendiri pada perilaku perdagangan suatu saham, ataupun dengan menggunakan sarana yang sudah disediakan dari analis di pasar modal, contohnya dealer, broker dan juga para manajer investasi. Dalam pasar modal, tidak semua saham dari perusahaan yang memiliki profil yang baik akan memberikan returnyang baik pada investor sehingga diperlukan analisis yang lebih mendalam mengenai perusahaan tersebut. Sebuah perusahaan mungkin saja mengalami return yang fluktuatif setiap saat karena berbagai macam faktor baik yang bersifat mikro maupun makro.

Bisnis properti dan real estate adalah bisnis yang dikenal memiliki karakteristik cepat berubah (volatile), persaiangan yang ketat, persisten, dan kompleks. Berdasarkan data dari Bursa Efek Indonesia, sejak tahun 2009 hingga 2016, hanya sekitar 
5\% atau kurang dari 30 saham emiten di BEI yang menghasilkan rata-rata imbal hasil (return) diatas $40 \%$ per tahun. Mayoritas emiten, yakni sekitar 58\% atau 300 saham, hanya menghasilkan rata-rata imbal hasil (return) sebesar 5\% per tahun. Sedangkan sisanya memiliki ratarata pertumbuhan moderat.

Perinciannya, sekitar 64 saham emiten atau $12 \%$ saham mencatatkan rata-rata imbal hasil (return) sebesar 30\%. Sebanyak 134 saham emiten memberikan imbal hasil (return) sebesar 20\%, dan lebih dari 200 saham menghasilkan return sebesar $10 \%$. (investasi.kontan; 2017). Kinerja perusahaan yang meningkat akan berpengaruh pada meningktanya harga saham dan diharapkan return saham yang dapat diterima investor meningkat. Data returnsaham properti dan real estate yang terdaftar di Bursa Efek Indonesia selama periode 2013-2017 dapat dilihat dalam grafik berikut:

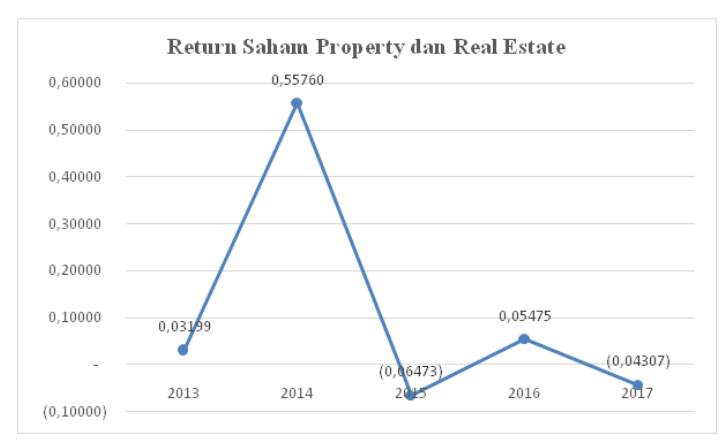

Posisi Return Saham

Properti dan Real Estate

Tahun 2013 - 2017

Dari grafik tersebut dapat dilihat bahwa secara keseluruhan, pergerakan returnsaham properti dan real estate dari tahun 2013 hingga tahun 2017 fluktuatif. Returnsaham properti dan real estate mencapai puncak tertinggi pada tahun 2014 sebesar 0.55760 dan pada tahun 2015 mencapai puncak terendah, yaitu -0.06473 . Dari grafik tersebut bisa disimpulkan bahwa return saham bisa mengalami kenaikan atau bahkan penurunan yang drastis.

Return saham pada tahun 2014 terlihat mencapai puncak tertinggi karena pada tahun ini harga properti cenderung kompetitif. Ada dua agenda politik besar pada tahun 2014, yaitu pemilihan legislatif dan presiden. Kedua agenda itu ditengarai berpengaruh terhadap aktivitas ekonomi, termasuk sektor properti. Sebab, pada tahun politik biasanya kondisi harga properti cenderung lebih kompetitif dan tidak mengalami banyak perubahan sehingga saham-saham dari emiten sektor properti dan real estate menjadi incaran para investor yang berburu capital gain, dimana investor juga tetap memperhatikan aspek fundamental perusahaan properti (Daily Investor; 2014).

Berbanding terbalik dengan penuruan drastis return saham pada tahun 2015. Rendahnya pertumbuhan propertimembuat indeks harga saham sektor ini turun. Awal tahun 2015 indeks saham properti pada Bursa Efek Indonesia berada pada level 532.96. Indeks ini sempat naik hingga menyentuh level tertinggi pada akhir Februari ke posisi 580.17. Kinerja sektor properti yang kurang baik membuat indeks sahamnya pun turun, bahkan mencapai 496.9, (katadata;2015).

Sepanjang tahun 2016 ternyata saham sektor properti masih belum pulih. Indeks sektor properti hanya naik sekitar 6 persen. 
Kenaikan ini tidak sebanding dengan Indeks Harga Saham Gabungan (IHSG) yang melesat 16.1 persen dalam periode yang sama.Data Bank Indonesia juga menunjukan kredit sektor properti hingga November 2016 juga hanya naik 7-9 persen.Padahal Pemerintah telah melonggarkan aturan agar permintaan terhadap properti kembali meningkat. (Bareksa;2016).

Selain itu, rendahnya daya beli masyarakat juga diindikasi sebagai penyebab menurunnya return saham perusahaan properti. Hal ini terbukti dari survei yang dilakukan Bank Indonesia (BI). Survei bank sentral terkait Indeks Keyakinan Konsumen (IKK) Juni 2017 sebesar 122.4 atau turun 3.5 poin jika dibandingkan dengan IKK pada bulan sebelumnya.Lemahnya kemampuan beli masyarakat ini membuat investasi properti tidak bergerak. Dengan kata lain, banyak investor yang tidak dapat menjual aset propertinya dengan harga yang lebih tinggi dari posisi beli. (cnnindonesia; 2017).

Dalam analisis fundamental terdapat beberapa rasio keuangan yang dapat mencerminkan kondisi keuangan dan kinerja suatu perusahaan. Robbert Ang (1997) mengelompokkan rasio keuangan ke dalam lima rasio yaitu rasio likuiditas, solvabilitas, profitabilitas, aktivitas dan rasio pasar. Rasio-rasio keuangan tersebut digunakan untuk menjelaskan kekuatan dan kelemahan dari kondisi keuangan suatu perusahaan serta dapat memprediksi returnsaham di pasar modal.

Rasio keuangan membantu dalam mengidentifikasi beberapa kekuatan dan kelemahan keuangan perusahaan. Dengan melakukan analisis rasio keuangan, maka akan diperoleh informasi mengenai penilaian keadaan perusahaan, baik yang telah lampau, saat sekarang, dan masa yang akan datang. Beberapa rasio keuangan yang dapat digunakan dalam memprediksi return saham antara lain Price earning ratio (PER), Earning per share (EPS), Return On Equity (ROE), Debt to Equity Ratio (DER) dan Net Profit Margin (NPM).

Berdasarkan fenomena diatas yang melihat fakta bahwa tidak adanya kepastian mengenai return yang akan didapatkan oleh investor ketika melakukan investasi saham, tentu seorang investor tidak ingin melakukan kesalahan dalam pengambilan keputusan investasi. Para investor pada umunya menggunakan teknik analisis fundamental untuk menilai kinerja perusahaan untuk mengestimasi return. infromasi dari laporan keuangan suatu perusahaan bisa menjadi media untuk para investor sebagai faktor fundamental untuk mengestimasi harga saham suatu perusahaan. Persoalan yang timbul adalah sejauh mana informasi perusahaan publik tersebut mempengaruhi harga saham di pasar modal dan faktor atau variabel apa saja yang menjadikan indikator, sehingga perusahaan dapat mengendalikannya dan tujuan meningkatkan nilai perusahaan melalui peningkatan nilai saham yang diperdagangkan di pasar modal dapat dicapai.

\section{KAJIAN PUSTAKA DAN PENGEMBANGAN HIPOTESIS}

\section{Kajian Teoritis}

Signaling

theory

menjelaskan tentang bagaimana para investor memiliki informasi yang sama dengan manajer perusahaan tentang prospek 
perusahaan, namun dalam kenyataan manajer sering memiliki informasi lebih baik dari investor luar. Hal ini sering disebut informasi asimetris, dan ini memiliki dampak penting pada struktur modal yang optimal (Yeye, 2012 dalam Affinanda 2015).

\section{Asimetri informasi} merupakan suatu kondisi dimana informasi privat yang hanya dimiliki investor-investor yang hanya mendapat informasi saja. Hal tersebut akan terlihat jika manajemen tidak secara penuh menyampaikan semua informasi yang diperoleh tentang semua hal yang dapat mempengaruhi perusahaan, maka umumnya pasar akan merespon informasi tersebut sebagai suatu sinyal terhadap suatu kejadian yang akan mempengaruhi nilai perusahaan yang tercermin melalui harga saham (Jogiyanto, 2000).

Reaksi pasar ditunjukkan dengan adanya perubahan volume perdagangan saham. Pada waktu informasi diumumkan dan semua pelaku pasar sudah menerima informasi tersebut, pelaku pasar terlebih dahulu menginterpretasikan dan menganalisis informasi tersebut sebagai sinyak baik (good news) atau sinyal buruk (bad news). Jika pengumuman informasi tersebut sebagai sinyal baik bagi investor, maka terjadi perubahan dalam volume perdagangan saham. Menurut Sharpe (1997), pengumuman informasi akuntansi memberikan sinyal bahwa perusahaan mempunyai prospek yang baik dimasa mendatang (good news) sehingga investor tertarik untuk melakukan perdagangan saham, dengan demikian pasar akan bereaksi yang tercermin melalui perubahan dalam volume perdagangan saham. Dengan demikian hubungan antara publikasi informasi baik laporan keuangan, kondisi keuangan ataupun social politik terhadap fluktuasi volume perdagangan saham dapat dilihat dalam efisiensi pasar. Menurut Husnan (2005), pasar modal efisien didefinisikan sebagai pasar yang harga sekuritassekuritasnya telah mencerminkan semua informasi yang relevan.

Secara garis besar signaling theory erat kaitannya dengan ketersediaan informasi. Berdasarkan informasi maka pasar modal dapat dibedakan menjadi (Jogiyanto, 2000):

- Pasar modal lemah (weak form)

Pasar yang harga-harga sekuritasnya mencerminkan informasi masa lalu.

- Pasar modal setengah kuat (Middle form)

Pasar yang harga-harga sekuritasnya secara penuh mencerminkan semua informasi yang dipublikasikan.

- Pasar modal kuat (strong form)

Pasar yang harga-harga sekuritasnya mancerminkan secara penuh semua jenis informasi termasuk informasi privat.

\section{Pengembangan Hipotesis}

- Pengaruh Price Earning Ratio terhadap Return Saham

PER dapat menjadi indikator pertumbuhan laba dan 
mengindikasikan pertumbuhan laba di masa yang akan datang. Rasio ini diperhatikan oleh pemodal/investor, memilih PER yang rendah menunjukkan nilai pasar yang tinggi atas saham karena semakin murah saham tersebut untuk dibeli dan semakin baik pula kinerja per lembar saham dalam menghasilkan laba bagi perusahaan. Semakin baik kinerja per lembar saham akan mempengaruhi banyak investor untuk membeli saham tersebut, sehingga saham tersebut akan diminati oleh investor dan pada akhirnya akan menaikkan pula harga sahamnya dan selanjutnya akan berdampak pada perolehan return saham. (Yani Prihantina Eka Furda et al, 2012).

Dalam penelitian yang dilakukan oleh Irman Firmansyah (2016), Eka Budi Yulianto dan Suratno (2015), Suherman Sodikin dan Nurul Wulandari (2016) menyatakan bahwa Price Earning Ratio (PER) memiliki pengaruh yang signifikan terhadap return saham.

Berdasarkan uraian mengenai pengaruh price earning ratio (PER) terhadap return saham, maka dapat dirumuskan hipotesis dalam penelitian ini sebagai berikut:

\section{$\mathrm{H}_{1}$ : Price Earning Ratio berpengaruh terhadap Return Saham.}

- Pengaruh Earning Per Share terhadap Return Saham

EPS yang tinggi maka dividen yang akan diterima investor semakin tinggi pula. Dividen yang akan diterima investor merupakan daya tarik bagi para investor/calon investor yang akan menanamkan dananya kedalam perusahaan tersebut. Daya tarik tersebut memberi dampak pada calon investor/investor untuk lebih meningkatkan kepemilikan saham perusahaan. (Yani Prihantina Eka Furda et al, 2012).

Dalam penelitian yang dilakukan oleh Satia Nur Maharani (2012), Gd Gilang Gunadi dan I Ketut Wijaya Kesuma (2015) menyatakan bahwa Earning Per Share (EPS) memiliki pengaruh yang signifikan terhadap return saham.

Berdasarkan uraian mengenai pengaruh earning per share terhadap return saham, maka dapat dirumuskan hipotesis dalam penelitian ini sebagai berikut:

$\mathrm{H}_{2}$ : Earning Per Share (EPS) berpengaruh positif dan signifikan terhadap return saham.

\section{- Pengaruh Return On Equity} terhadap Return Saham

Dalam menentukan pilihannya, investor biasanya akan mempertimbangkan perusahaan yang mampu memberikan kontribusi Return on equity (ROE) yang lebih besar. Bagi investor semakin tinggi Return on equity (ROE) menunjukkan risiko investasi semakin kecil. Indikator Returnon Equity (ROE) yang meningkat sangat penting diperhatikan untuk mengetahui investasi yang akan dilakukan investor. Dengan Return on equity (ROE) yang tinggi suatu perusahaan mampu memberikan return sesuai dengan tingkat yang diharapkan; meningkatnya Return on equity (ROE) akan meningkatkan return saham. (Eka Budi Yulianti et al, 2015).

Dalam penelitian yang dilakukan oleh Eka Budi Yulianti dan Suratno (2015), Stefanus Antara et al. (2014), 
Michael Aldo Carlo (2014) menyatakan bahwa Return On Equity (ROE) memiliki pengaruh yang signifikan terhadap return saham. Berdasarkan uraian mengenai pengaruh return on equity (ROE) terhadap return saham, maka dapat dirumuskan hipotesis dalam penelitian ini sebagai berikut:

$$
\begin{array}{rlr}
\mathrm{H}_{3} \text { : } & \begin{array}{l}
\text { Return On Equity } \\
\text { berpengaruh }
\end{array} & \text { positif } \\
& \text { signifikan } \\
& \text { daham. }
\end{array}
$$

\section{- Pengaruh Debt to Equity Ratio terhadap Return Saham}

Debt to equity ratio menunjukkan seberapa besar aktiva perusahaan dibiayai oleh hutang atau seberapa besar hutang perusahaan berpengaruh terhadap pengelolaan ekuitas. Debt to equity ratio diperoleh dengan total hutang dibagi dengan total ekuitas, setiap rupiah modal dijadikan jaminan untuk keseluruhan utang. Debt to equity ratio yang semakin besar akan mengakibatkan risiko financial perusahaan semakin tinggi. Dengan penggunaan hutang yang semakin besar akan mengakibatkan semakin tinggi risiko untuk tidak mampu membayar hutang. Investor biasanya menghindari risiko, maka semakin tinggi Debt to equity ratio (DER) akan mengakibatkan saham perusahaan tersebut dihindari investor, sehingga harga saham semakin rendah. Dengan meningkatnya Debt to equity ratio (DER) berarti akan meningkatkan risiko berinvestasi, dengan demikian investor merespon negatif terhadap kinerja perusahaan. Rendahnya kinerja perusahaan berakibat harga saham akan mengalami penurunan. Menurunnya harga saham akan mengakibatkan return yang semakin menurun.
Dalam penelitian yang dilakukan oleh Irman Firmansyah (2016), Arifah Rusydina dan Sugeng Praptoyo (2017) menyatakan bahwa Debt to Equity Ratio (DER) memiliki pengaruh yang signifikan terhadap return saham.

Berdasarkan uraian mengenai pengaruh debt to equity ratio (DER) terhadap return saham, maka dapat dirumuskan hipotesis dalam penelitian ini sebagai berikut:
$\mathrm{H}_{4}$ : Debt to Equity Ratio (DER) berpengaruh positif dan signifikan terhadap return saham.

- Pengaruh Net Profit Margin terhadap Return Saham

Net Profit Margin (NPM) yang tinggi memberikan sinyal akan keberhasilan perusahaan dalam mengembang misi dari pemiliknya. Perusahaan yang mampu menghasilkan keuntungan akan mempengaruhi investor maupun calon investor untuk melakukan investasi. Investor akan bersedia membeli saham dengan harga lebih tinggi apabila memperkirakan tingkat Net Profit Margin (NPM) perusahaan naik, dan sebaliknya investor tidak bersedia membeli saham dengan harga tinggi apa bila nilai Net Profit Margin (NPM) perusahaan rendah. Net Profit Margin (NPM) perusahaan yang meningkat akan menyebabkan investor memburu suatu saham perusahaan akibatnya return perusahaan tersebut akan meningkat pula.

Dalam penelitian yang dilakukan oleh Ferdinan Eka Putra dan Paulus Kindangen (2016), menyatakan bahwa Net Profit Margin (NPM) 
memiliki pengaruh yang signifikan terhadap return saham.

Berdasarkan uraian mengenai pengaruh net profit margin (NPM) terhadap return saham, maka dapat dirumuskan hipotesis dalam penelitian ini sebagai berikut:

$$
\begin{array}{rlrr}
\mathrm{H}_{5}: & \begin{array}{l}
\text { Net Profit } \\
\text { berpengaruh }
\end{array} & \begin{array}{r}
\text { Margin } \\
\text { positif }
\end{array} & \begin{array}{r}
\text { dan } \\
\text { signifikan } \\
\text { saham. }
\end{array} \\
\text { terhadap } & \text { return }
\end{array}
$$

\section{METODE PENELITIAN Populasi dan Sampel}

Metode penelitian sampel yang digunakan adalah Purposive Sampling, yaitu tipe pemilihan sampel berdasarkan pertimbanganpertimbangan tertentu dan pertimbangan yang diambil itu berdasarkan tujuan penelitian. Sampel untuk penelitian ini adalah Perusahaan properti dan real estate yang terdaftar di Bursa Efek Indonesia (BEI) periode tahun 2013 sampai dengan tahun 2017. Dari hasil pemilihan sampel dengan menggunakan Purposive Sampling terpilih 16 perusahaan yang memenuhi kriteria.

\section{Definisi Operasional Variabel Return Saham (Y)}

Return saham merupakan tujuan utama seorang investor dalam berinvestasi yaitu untuk mendapatkan keuntungan dari investasi tersebut. Return merupakan salah satu faktor yang memotivasi investor dalam berinvestasi dan juga merupakan imbalan atas keberanian investor menanggung risiko atas investasi yang dilakukannya (Thamrin, 2012).

Pada penelitian ini konsep return yang digunakan adalah perhitungan return realisasi yang menggunakan capital gain/capital loss yang merupakan selisih antara saham periode saat ini $(\mathrm{Pt})$ dengan harga saham pada periode sebelumnya (Pt-1) dengan mengabaikan kebijakan dividen. Alasan digunakan capital gain, karena tidak semua perusahaan membagikan dividen.

Menurut Jogiyanto (2012: 206), return saham dihitung dengan menggunakan rumus sebagai berikut:

$R_{i t}=\frac{\mathrm{P}_{i t}-\left(\mathrm{P}_{i t}-1\right)}{\mathrm{P}_{i t}-1}$

Dimana:

$\mathrm{R}_{\mathrm{it}}=$ Return realisasian untuk saham

I pada waktu ke $\mathrm{t}$

Pit $=$ Harga saham pada periode ke $t$ $\mathrm{P}_{\mathrm{it}}-1=$ Harga saham pada periode ke $\mathrm{t} 1$

\section{Price earning ratio (X1)}

Price earning ratio (PER) adalah cara mengukur seberapa besar investor menilai laba yang dihasilkan perusahaan. Price earning ratio (PER) penting karena jumlah laba yang dihasilkan perusahaan sebetulnya akan menentukan jumlah dividen yang akan bisa dibayarkan di masa yang akan datang. Jika labanya naik maka dividen juga akan naik.Rasio ini menggambarkan ketersediaan investasi membayar suatu jumlah tertentu untuk setiap perolehan laba perusahaan.

Price earning ratio dapat dihitung dengan perbandingan anatara harga pasar per lembar saham dan laba bersih per lembar saham. Semakin meningkatnya Price earning ratio (PER) mencerminkan kinerja perusahaan. Meningkatnya kinerja perusahaan memberikan respon positif bagi investor, yang mengakibatkan meningkatnya harga saham. Semakin menigkatnya harga saham dengan sendirinya meningkatnya abnormal return saham. (Eka Budi Yulianti et al, 2015). 
Perhitungan price earning ratio (PER) menggunakan rumus sebagai berikut:

Price Earning Ratio $(P E R)=\frac{\text { Harga per lembar saham }}{\text { Laba bersih per lembar saham(EPS) }}$

\section{Earning per share (X2)}

Earning per share (EPS) merupakan perbandingan antara laba bersih dengan jumlah saham beredar. EPS menunjukkan keberhasilan perusahaan dalam memperoleh laba dari setiap sahamnya atas operasional pada suatu periode. Secara langsung EPS dipengaruhi oleh pendapatan perusahaan sehingga jika rasio EPS tinggi maka berdampak pada peningkatan return saham, karena investor akan menilai bahwa perusahaan dalam keadaan baik.

Kenaikan earning per share berarti perusahaan sedang dalam tahap pertumbuhan atau kondisi keuangannya sedang mengalami peningkatan dalam penjualan dan laba, atau dengan kata lain semakin besar earning per share menandakan kemampuan perusahaan dalam menghasilkan keuntungan bersih setiap lembar saham. (Suherman et al, 2016).

Perhitungan earning per share (EPS) menggunakan rumus sebagai berikut:

Earning Per Share $($ EPS $)=\frac{\text { Laba bersih setelah pajak }}{\text { Jumlah lembar sahamyang beredar }}$

\section{Return on equity (X3)}

Return on equity (ROE) adalah rasio untuk mengukur seberapa efektif perusahaan memanfaatkan kontribusi pemilik dan atau seberapa efektifnya perusahaan memanfaatkan sumbersumber lain untuk kepentingan pemilik. Rumus untuk Return on equity (ROE) yaitu dengan membagi Net Income After Tax (NIAT) dengan shareholder equity (Brigham dan Houston dalam Eka Budi Yulianti (2015)). Return on equityataureturn on net worth mengukur kemampuan perusahaan memperoleh laba yang tersedia bagi pemegang saham perusahaan atau untuk mengetahui besarnya kembalian yang diberikan oleh perusahaan untuk setiap rupiah modal dari pemilik (Sugiarti et al, 2015).

Perhitungan return on equity (ROE) menggunakan rumus sebagai berikut:

Return On Equity $(R O E)=\frac{\text { Laba bersih setelah pajak }}{\text { Ekuitas pemegang saham }} X 100 \%$

\section{Debt to equity ratio $(\mathrm{X} 4)$}

Debt to equity ratio (DER) adalah perbandingan jumlah hutang yang ditanggung perusahaan dengan modal sendiri yang dimiliki perusahaan. Debt to equity ratiomenunjukkan seberapa besar aktiva perusahaan dibiayai oleh hutang atau seberapa besar hutang perusahaan berpengaruh terhadap pengelolaan akuitas. Debt to equity ratio diperoleh dengan total hutang dibagi dengan total ekuitas, setiap rupiah modal dijadikan jaminan untuk keseluruhan utang (Eka Budi Yulianti et al, 2015).

Rasio ini berguna untuk mengetahui jumlah dana yang disediakan peminjam (kreditor) dengan pemilik perusahaan. Dengan kata lain, rasio ini berfungsi untuk mengetahui setiap rupiah modal sendiri yang dijadikan untuk jaminan utang (Sugiarti et al, 2015).

Perhitungan debt to equity ratio (DER) menggunakan rumus sebagai berikut:

Debt to Equity Ratio $(D E R)=\frac{\text { Total Hutang }}{\text { Total Ekuitas }} \mathrm{X} 100 \%$ 


\section{Net profit margin (X5)}

Menurut Alexandri (2008: 200) Net Profit Margin adalah rasio yang digunakan untuk menunjukkan kemampuan perusahaan dalam menghasilkan keuntungan bersih setelah dipotong pajak. Menurut Bastian dan Suhardjono (2006: 299) Net Profit Margin adalah perbandingan antara laba bersih dengan penjualan. Semakin besar Net Profit Margin, maka kinerja perusahaan akan semakin produktif, sehingga akan meningkatkan kepercayaan investor untuk menanamkan modalnya pada perusahaan tersebut. Rasio ini menunjukkan berapa besar persentase laba bersih yang diperoleh dari setiap penjualan. Semakin besar rasio ini, Maka dianggap semakin baik kemampuan perusahaan untuk mendapatkan laba yang tinggi.

Hubungan antara laba bersih sesudah pajak dan penjualan bersih menunjukkan kemampuan manajemen dalam mengemudikan perusahaan secara cukup berhasil untuk menyisakan margin tertentu sebagai kompensasi yang wajar bagi pemilik yang telah menyediakan modalnya untuk suatu resiko. Hasil dari perhitungan mencerminkan keuntungan netto per rupiah penjualan. Para investor pasar modal perlu mengetahui kemampuan perusahaan untuk menghasilkan laba. (Hery Heryawan, 2013).

Perhitungan net profit margin (NPM) menggunakan rumus sebagai berikut:

Net Profit Margin $($ NPM $)=\frac{\text { Laba Bersih Setelah Pajak }}{\text { Penjulan }}$

\section{Pegujian Hipotesis}

Uji Hipotesis secara bersama-sama (Uji Model)

pengujian ini dimaksudkan untuk membuktikan apakah semua variabel eksogen yang terdapat dalam suatu model memiliki pengaruh secara bersama-sama terhadap variabel endogen. adapun kriteria dalam pengambilan suatu keputusan berdasarkan pembuktian diatas adalah sebagai berikut:

- Jika nilai sig probabilitas $<0,05$, maka $\mathrm{H}_{1}$ diterima

- Jika nilai sig probabilitas > 0,05, maka $\mathrm{H}_{0}$ diterima

\section{Koefisien Determinasi}

Pengujian koefisien determinasi

(R2) bertujuan untuk mengukur kemampuan model dalam menerangkan variabel Eksogen terhadap Endogen. Besarnya nilai koefisien determinasi adalah antara nol sampai dengan satu. Jika nilai koefisien determinasi suatu model semakin besar (60\% s/d 90\%) dalam menghasilkan nilainya koefesiennya, maka hal tersebut dapat dikatakan bahwa variabel eksogen tersebut mampu memberikan hampir semua informasi yang dibutuhkan untuk menerangkan variasi pada variabel dependen.

\section{Uji Hipotesis Secara Parsial (Uji t)}

Uji hipotesis ini dilakukan untuk mengetahui ada/atau tidaknya pengaruh variabel bebas dengan variabel terikatnya secara parsial. Pengujian secara simultan ini dilakukan dengan cara membandingkan antara tingkat signifikansi t dari hasil pengujian dengan nilai signifikansi yang digunakan dalam penelitian ini. Cara pengujian parsial terhadap variabel independen yang digunakan dalam penelitian ini adalah sebagai berikut:

- Jika nilai sig probabilitas $<0,05$, maka Ha diterima.

- Jika nilai sig probabilitas > 0,05, maka H0 diterima

\section{Analisis Regresi Data Panel}


Data panel merupakan gabungan antara data runtut waktu (time series) dan data silang (cross section) (Winarno; 2015). Data cross section merupakan data yang terdiri atas suatu objek namun meliputi beberapa objek pada suatu periode waktu, sedangkan data time series merupakan data yang tersiri atas satu objek namun meliputi beberapa periode waktu (Winarno; 2015).

\section{HASIL DAN PEMBAHASAN \\ Hasil Analisis Statistik Deskriptif}

Statistik deskriptif memberikan gambaran suatu data yang dapat dilihat dari nilai rata-rata, standar deviasi, nilai maksimum, dan nilai minimum, Selengkapnya mengenai hasil statistik deskriptif penelitian berikut:

\begin{tabular}{|l|c|c|c|c|c|c|}
\hline & RETURN & PER & EPS & ROE & DER & NPM \\
\hline Mean & 0.093000 & 73.01400 & 226.6328 & 10.78613 & 0.486000 & 0.291000 \\
\hline Median & -0.025000 & 14.06000 & 26.98500 & 8.255000 & 0.485000 & 0.280000 \\
\hline Maximum & 2.250000 & 3113.360 & 1308.300 & 40.85000 & 1.120000 & 0.720000 \\
\hline Minimum & -0.750000 & 2.180000 & 0.020000 & 0.040000 & 0.030000 & 0.010000 \\
\hline Std. Dev. & 0.494152 & 351.3821 & 364.0603 & 9.411368 & 0.236363 & 0.186069 \\
\hline $\begin{array}{l}\text { Observation } \\
\text { s }\end{array}$ & 80 & 80 & 80 & 80 & 80 & 80 \\
\hline Suumber
\end{tabular}

Sumber: Hasil Olahan Eviews 9, 2018

Rata - Rata Nilai Return Saham memiliki nilai minimum sebesar 0.750000 pada perusahaan GAMA tahun 2013, sedangkan untuk nilai maksimumnya sebesar 2.250000 pada perusahaan SCBD tahun 2013, memiliki nilai rata-rata sebesar 0.093000 , dan standar deviasi sebesar 0.494152 .

ratio, memiliki nilai minimum sebesar 2.180000 pada perusahaan JIHD tahun 2013, sedangkan untuk nilai maksimum sebesar 3113.360 pada perusahaan GAMA tahun 2017, Memiliki nilai rata-rata sebesar 73.01400, dan standar deviasi sebesar 351.3821.
Rata-rata Nilai earning per share, memiliki nilai minimum sebesar 0.020000 pada perusahaan GAMA tahun 2017, sedangkan nilai maksimum sebesar 1308.300 pada perusahaan LPCK tahun 2015, memiliki nilai rata-rata sebesar 226.6328, dan standar deviasi sebesar 364.0603 .

Rata-rata Nilai return on equity, memiliki nilai minimum sebesar 0.040000 pada perusahaan GAMA tahun 2017, sedangkan nilai maksimumnya sebesar 40.85000 pada perusahaan SCBD tahun 2013 , memiliki nilai rata-rata sebesar 10.78613, dan memiliki standar deviasi sebesar 9.411368.

Rata-rata NIlai debt to equity ratio, memiliki nilai minimum sebesar 0.030000 pada perusahaan BAPA tahun 2017, sedangkan nilai maksimumnya sebesar 1.120000 pada perusahaan LPCK tahun 2013, memiliki nilai rata-rata sebesar 0.486000 , dan memiliki standar deviasi sebesar 0.236363 .

Rata-rata Nilai net profit margin, memiliki nilai minimum sebesar 0.010000pada perusahaan GPRA tahun 2017, sedangkan nilai maksimumnya sebesar 0.720000pada perusahaan BSDE tahun 2014, memiliki nilai rata-rata sebesar 0.291000, dan memiliki standar deviasi sebesar 0.186069 .

\section{Hasil Uji Chow (Common Effect vs Fixed Effect)}

Pengujian ini dapat dilihat pada nilai Probabilitas (Prob,) Cross-section F dan Cross-section chi-square dengan hipotesis sebagai berikut:

$\mathrm{H}_{0}$ : Model mengikuti Common Effect Model (CEM) jika Probabilitas Cross-section $\mathrm{F}$ dan Cross-section chi-square $>\alpha(0,05)$ 
$\mathrm{H}_{\mathrm{a}}$ : Model mengikuti Fixed Effect Model (FEM) jika Probabilitas Cross-section $\mathrm{F}$ dan Cross-section chi-square $<\alpha(0,05)$
Redundant Fixed Effects Tests

Equation: EQ01

Test cross-section fixed effects

\begin{tabular}{|lrrr|}
\hline \hline Effects Test & Statistic & d.f. & Prob. \\
\hline \hline Cross-section F & 1.655511 & $(15,59)$ & 0.0864 \\
Cross-section Chi-square & 28.102825 & 15 & 0.0209 \\
\hline
\end{tabular}

Sumber: Hasil Olahan Eviews 9, 2018

Pada hasil uji chow terlihat bahwa nilai Prob. Cross-section F sebesar 0,0864 yang nilainya $>0,05$ sehingga dapat disimpulkan bahwa model Common Effect Model (CEM) lebih baik dibandingkan dengan model Fixed Effect Model (FEM).

\section{Hasil Uji Langrage Multiplier (Common Effect vs Random Effect)}

Menurut Basuki dan Prawoto (2016) untuk mengetahui apakah model Random Effects Model (REM) lebih baik daripada model Common Effect Model (CEM) digunakan uji Lagrange Multiplier (LM), Hipotesis yang digunakan dengan uji LM adalah sebagai berikut:

H0 : Model mengikuti Common Effect Model (CEM) jika nilai Probabilitas Cross-section Breush-pagan $>\alpha$ $(0,05)$

Ha : Model mengikuti Random Effect Model (REM) jika nilai Probabilitas Cross-section Breush-pagan $<\alpha$ $(0,05)$

Lagrange Multiplier Tests for Random Effects Null hypotheses: No effects

Alternative hypotheses: Two-sided (Breusch-Pagan) and one-sided

(all others) alternatives

\begin{tabular}{|lccc|}
\hline \hline & \multicolumn{3}{c|}{ Test Hypothesis } \\
& Cross-section & Time & Both \\
\hline \hline Breusch-Pagan & $\begin{array}{l}0.001801 \\
(0.9662)\end{array}$ & $\begin{array}{l}0.095460 \\
(0.7573)\end{array}$ & $\begin{array}{l}0.097260 \\
(0.7551)\end{array}$ \\
\hline
\end{tabular}

Sumber: Hasil Olahan Eviews 9, 2018

Pada hasil uji Lagrange Multiplier terlihat bahwa nilai Prob. Cross-section Breusch-Pagan sebesar 0,9662 yang nilainya > 0,05 sehingga dapat disimpulkan bahwa model Common Effect Model (CEM) lebih baik dibandingkan dengan model Random Effect Model (REM).

\section{Kesimpulan Model}

Berdasarkan pengujian perpasangan terhadap ketiga model regresi data panel diatas dapat disimpulkan bahwa model Common Effect Model (CEM) dalam regresi data panel digunakan lebih lanjut dalam pengaruh price earning ratio, earning per share, return on equity, debt to equity ratio dan net profit margin terhadap 16 perusahaan properti dan real estate yang dijadikan sampel dalam penelitian ini selama periode $2013-2017$.

\begin{tabular}{|c|c|c|c|}
\hline No. & Metode & Pengujian & Hasil \\
\hline 1 & $\begin{array}{c}\text { Chow } \\
\text { Test }\end{array}$ & $\begin{array}{c}\text { Common } \\
\text { Effect vs } \\
\text { Fixed Effect }\end{array}$ & $\begin{array}{c}\text { Common } \\
\text { Effect }\end{array}$ \\
\hline \multirow{2}{*}{2} & $\begin{array}{c}\text { Lagrange } \\
\text { Multiplier } \\
\text { Test } \\
\text { (LM- } \\
\text { Test) }\end{array}$ & $\begin{array}{c}\text { Common } \\
\text { Effect vs } \\
\text { Random } \\
\text { Effect }\end{array}$ & $\begin{array}{c}\text { Common } \\
\text { Effect }\end{array}$ \\
\hline
\end{tabular}

\section{Hasil Uji Multikolonieritas}

Uji Multikolinearitas perlu dilakukan pada regresi yang menggunakan lebih dari satu variabel 
bebas, hal ini untuk mengetahui apakah terjadi hubungan saling mempengaruhi antara variabel bebas yang diteliti. Maka menghasilkan output sebagai berikut:

\begin{tabular}{|c|c|c|c|c|c|}
\hline & PER & EPS & ROE & DER & NPM \\
\hline PER & 1.000000 & -0.108535 & -0.186655 & -0.121139 & -0.238411 \\
\hline EPS & -0.108535 & 1.000000 & 0.700248 & 0.007962 & 0.607842 \\
\hline ROE & -0.186655 & 0.700248 & 1.000000 & 0.192117 & 0.762922 \\
\hline DER & -0.121139 & 0.007962 & 0.192117 & 1.000000 & -0.083116 \\
\hline NPM & -0.238411 & 0.607842 & 0.762922 & -0.083116 & 1.000000 \\
\hline
\end{tabular}

Sumber: Hasil Olahan Eviews 9, 2018

Berdasarkan gambar output diatas dapat dilihat tidak terdapat variabel indepeden yang memiliki nilai lebih dari 0,8 . Sehingga dapat disimpulkan tidak terjadi multikolinearitas dalam model regresi.

\section{Hasil Uji Heteroskedastisitas}

Keputusan terjadi atau tidaknya heterokedastisitas pada model regresi adalah melihat nilai Prob.Breusch-Pagan LM dengan hipotesis sebagai berikut:

H0 : Tidak Terjadi Heteroskedastisitas Ha : Terjadi Heteroskedastisitas.

Jika nilai Prob.Breusch-Pagan LM lebih besar dari tingkat $\alpha 0,05$, maka $\mathrm{H}_{0}$ diterima artinya tidak terjadi heteroskedastisitas. Apabila nilai Prob.Breusch-Pagan LM lebih kecil $\alpha$ 0,05, maka Ha diterima yang artinya terjadi heteroskedastisitas.

\begin{tabular}{|l|c|c|l|}
\hline \multicolumn{1}{|c|}{ Test } & Statistic & d.f. & Prob. \\
\hline Breusch-Pagan LM & 137.0613 & 120 & 0.1366 \\
\hline Pesaran scaled LM & 0.068508 & & 0.9454 \\
\hline Pesaran CD & 0.857464 & & 0.3912 \\
\hline
\end{tabular}

Sumber: Hasil Olahan Eviews 9, 2018

Berdasarkan pada tabel diatas, dapat dilihat nilai Prob. Breusch-Pagan
LM sebesar $0.1366>\alpha 0,05$, dengan demikian maka dapat disimpulkan bahwa model regresi data penel tidak terjadi heteroskedstisitas.

\section{Hasil Uji F}

\begin{tabular}{ll}
\hline \hline F-statistic & 8.590491 \\
Prob(F-statistic) & 0.000002 \\
\hline \hline
\end{tabular}

Sumber: Hasil Olahan Eviews 9, 2018

Dengan menggunakan dasar keputusan seperti diatas, diketahui berdasarkan $\mathrm{F}_{\text {tabel }}$ dengan perhitungan $\mathrm{df}_{1}$ $=5-1$ dan $\mathrm{df}_{2}=80-5-1$ dengan tingkat $\alpha=5 \%$, maka didapati nilai sebesar $\mathrm{df}_{1}=4$ dan $\mathrm{df}_{2}=74$ lalu diperoleh nilai $F_{\text {tabel }}$ sebesar 2.50. Maka dapat disimpulkan $F_{\text {hitung }}$ (8.5904) $>F_{\text {tabel }}$ (2.50), yang artinya menolak $\mathrm{H}_{0}$ dan menerima $\mathrm{H}_{\mathrm{a}}$.

Dapat disimpulkan bahwa terdapat pengaruh secara bersama-sama antara Price Earning Ratio (PER), Earning Per Share (EPS), Return On Equity (ROE), Debt to Equity Ratio (DER) dan Net Profit Margin (NPM) terhadap Return Saham Pada Perusahaan properti dan real estate yang terdaftar di Bursa Efek Indonesia (BEI) periode tahun 2013 sampai dengan tahun 2017

\section{Hasil Koefisien Determinasi}

\begin{tabular}{ll}
\hline \hline R-squared & 0.367264 \\
Adjusted R-squared & 0.324512 \\
\hline \hline
\end{tabular}

Dari hasil perhitungan tersebut diperoleh besarnya pengaruh variabel Eksogen terhadap variabel Endogen yang dapat diterangkan oleh model dalam persamaan ini adalah sebesar 0.324512 atau sebesar $32.5 \%$. Hal ini menunjukan bahwa Price Earning Ratio (PER), 
Earning Per Share (EPS), Return On Equity (ROE), Debt to Equity Ratio (DER) dan Net Profit Margin (NPM) mampu menjelaskan variasi naik/turunnya Return Saham sebesar $32.5 \%$ sedangkan sisanya sebesar $67.5 \%$ dijelaskan oleh faktor - faktor lain selain yang tidak dimasukan dalam model regresi

ini.

\section{Hasil Uji t}

\begin{tabular}{ccccc}
\multicolumn{5}{l}{ Dependent Variable: Return Saham } \\
\hline \hline Variable & Coefficient & Std. Error & t-Statistic & Prob. \\
\hline \hline C & -0.090909 & 0.146593 & -0.620142 & 0.5371 \\
PER & 0.000175 & 0.000136 & 1.287299 & 0.2020 \\
EPS & -0.000271 & 0.000180 & -1.509144 & 0.1355 \\
ROE & 0.044563 & 0.009280 & 4.802016 & 0.0000 \\
DER & -0.303298 & 0.215653 & -1.406417 & 0.1638 \\
NPM & -0.345689 & 0.418108 & -0.826794 & 0.4110 \\
\hline \hline
\end{tabular}

Sumber: Hasil Olahan Eviews 9, 2018

Dari tabel diatas hasil analisis regresi data panel didapatkan sebagai berikut:

Return Saham $=-0.090909+0.000175$ PER 0.000271EPS + 0.044563ROE - 0.0303298DER $0,345689 \mathrm{NPM}+\varepsilon$

Berdasarkan hasil perhitungan menggunakan Eviews 9.0 dapat dilihat bahwa dari kelima variabel diatas yakni Current Ratio, Account Receivable Turnover, Inventory Turnover, Total Asset Turnover dan Debt To Equity terhadap Return on Asset.

\section{PEMBAHASAN}

\section{Pengaruh Price Earning Ratio terhadap Return Saham}

Hipotesis pertama yang diajukan menyatakan bahwa Price Earning Ratio tidak berpengaruh terhadap Return Saham. Hasil uji koefisien regresi Price Earning Ratio pada hasil output eviews 9.0 diatas menunjukkan tingkat Prob sebesar 0,202 atau lebih besar dari $0,05(0,202>0,05)$ dan nilai t-statistic sebesar 1,287 atau $(1,287<1,992)$ dimana t-statistic lebih kecil dari $t_{\text {tabel }}$ yang artinya Price Earning Ratio tidak berpengaruh terhadap Price Earning Ratio sehingga $\mathrm{H}_{1}$ ditolak.

Terbukti pada PT. Gading Development, tbk dan Kawasan Industri Jababeka Tbk tahun dari tahun 2013 - 2017 yang memiliki nilai Price Earning Ratio yang tinggi tidak memberikan pengaruh terhadap nilai Return sahamnya. Hal ini berarti menunjukkan bahwa Price Earning Ratio tidak memiliki pengaruh yang signifikan terhadap return saham syariah disebabkan karena Price Earning Ratio lebih banyak berhubungan dengan faktor lain diluar return saham, ketidakpastian kondisi ekonomi dan politik serta sentimen dari pasar bursa itu sendiri.

Karena Price Earning Ratio merupakan harapan atau ekspektasi investor terhadap kinerja suatu perusahaan yang dinyatakan dalam rasio. Kesediaan investor untuk menerima kenaikan Price Earning Ratio sangat bergantung kepada prospek perusahaan. Price Earning Ratio menjadi tidak mempunyai makna apabila perusahaan mempunyai laba yang sangat rendah atau menderita kerugian, dalam keadaan ini Price Earning Ratio perusahaan akan begitu tinggi atau bahkan negatif.

Hasil penelitian ini sejalan dengan penelitian yang dilakukan oleh Dedy Oktri Hadi Saputra dan Rini Indriani (2012) yang menyatakan price earning ratio tidak berpengaruh terhadap return saham, sedangkan berbeda dengan penelitian Irman Firmansyah (2016) menyatakan price 
earning ratio berpengaruh terhadap return saham.

\section{Pengaruh Earning Price Share terhadap Return Saham}

Hipotesis kedua yang diajukan menyatakan bahwa Earning Price Share tidak berpengaruh terhadap Return Saham. Hasil uji koefisien regresi Earning Price Share pada hasil output eviews 9.0 diatas menunjukkan tingkat Prob sebesar 0,135 atau lebih besar dari $0,05(0,135>0,05)$ dan nilai t-statistic sebesar $-1,509$ atau ($1,509>-1,992)$ dimana t-statistic lebih besar dari $t_{\text {tabel }}$ yang artinya Earning Price Share tidak berpengaruh terhadap Return Saham sehingga $\mathrm{H}_{2}$ ditolak.

Terbukti pada PT. Lippo Cikarang Tbk dan PT. Roda Vivtex Tbk dari tahun 2013 - 2017 yang memiliki nilai Earning Price Share yang tinggi tidak memberikan pengaruh terhadap nilai Return Saham. Hal ini berarti kenaikan atau penurunan nilai Earning Price Share tidak berdampak pada kenaikan atau penurunan return saham. Nilai Earning Price Share yang semakin tinggi tidak berarti akan memberikan kontribusi terhadap return saham yang semakin tinggi atau sebaliknya nilai Earning Price Share yang semakin rendah tidak akan selalu memberikan kontribusi terhadap return saham yang semakin rendah.

Hasil analisis ini mengindikasikan bahwa investor tidak menggunakan EPS sebagai parameter untuk mengukur kinerja perusahaan guna memprediksi return saham di Bursa Efek Indonesia (BEI). Bahkan besarnya EPS tergantung dari jumlah saham yang diedarkan, semakin banyak saham yang beredar maka EPS dapat bernilai kecil meskipun laba yang dihasilkan perusahaan besar. Hal ini tidak sesuai dengan teori yang mendasari bahwa EPS yang semakin besar akan menunjukkan kemampuan perusahaan dalam menghasilkan laba bersih setelah pajak semakin meningkat.

Hal ini sejalan dengan penelitian Irman Firmansyah (2016) yang menyatakan earning per share tidak berpengaruh terhadap return saham, sedangkan berbeda dengan penelitian Satia Nur Maharani (2012) menyatakan earning per share berpengaruh terhadap return saham.

\section{Pengaruh Return on Equity terhadap Return Saham}

Hipotesis ketiga yang diajukan menyatakan bahwa Return On Equity berpengaruh Positif terhadap Return Saham. Hasil uji koefisien regresi Return On Equity pada hasil output eviews 9.0 diatas menunjukkan tingkat Prob sebesar 0,000 atau lebih kecil dari $0,05(0,000<0,05)$ dan nilai t-statistic sebesar 4,802 atau $(4,802>1,992)$ dimana t-statistic lebih besar dari $t_{\text {tabel }}$ yang artinya Return On Equity berpengaruh Positif dan signifikan terhadap Return Saham sehingga $\mathrm{H}_{3}$ diterima.

Terbukti pada PT. Metropolitan Kentjana Tbk dan PT. Roda Vivtex Tbk dari tahun 2013 - 2017 yang memiliki Return On Equity yang tinggi dan menyebabkan nilai Return Saham meningkat. Hal tersebut berarti menunjukkan bahwa Return on equity (ROE) merupakan salah satu indikator penting untuk menilai prospek perusahaan di masa yang akan datang. Dengan mengetahui tingkat Return on equity investor dapat melihat pertumbuhan profitabilitas perusahaan. Indikator Return on equity (ROE) sangat 
penting diperhatikan untuk mengetahui investasi yang akan dilakukan investor di suatu perusahaan mampu memberikan return yang sesuai dengan tingkat yang diharapkan.

$\begin{array}{crr}\text { Dalam } & \begin{array}{r}\text { menentukan } \\ \text { biasanya }\end{array} & \text { pilihannya, } \\ \text { investor } & \text { akan }\end{array}$ mempertimbangkan perusahaan yang mampu memberikan kontribusi Return on equity (ROE) yang lebih besar. Bagi investor semakin tinggi Return on equity (ROE) menunjukkan risiko investasi semakin kecil. Indikator Return On Equity (ROE) yang meningkat sangat penting diperhatikan untuk mengetahui investasi yang akan dilakukan investor. Dengan Return on equity (ROE) yang tinggi suatu perusahaan mampu memberikan return sesuai dengan tingkat yang diharapkan; meningkatnya Return on equity (ROE)akan meningkatkan return saham. (Eka Budi Yulianti et al, 2015).

Hal ini sejalan dengan penelitian Eka Budi Yulianti dan Suratno (2015) yang menyatakan return on equity berpengaruh terhadap return saham, sedangkan berbeda dengan penelitian Sugiarti (2015) menyatakan return on equity tidak berpengaruh terhadap return saham.

\section{Pengaruh Debt to Equity terhadap Return Saham}

Hipotesis keempat yang diajukan menyatakan bahwa Debt To Equity berpengaruh terhadap Return Saham. Hasil uji koefisien regresi Debt To Equity pada hasil output eviews 9.0 diatas menunjukkan tingkat Prob sebesar 0,164 atau lebih besar dari $0,05(0,164>0,05)$ dan nilai t-statistic sebesar $-1,406$ atau $(-1,406>-1,992)$ dimana $t$-statistic lebih besar dari $t_{\text {tabel }}$ yang artinya Debt To Equity tidak berpengaruh terhadap Return Saham sehingga $\mathrm{H}_{4}$ ditolak.

Terbukti pada PT. Duta Anggada Realty Tbk. dan PT. Kawasan Industri Jababeka Tbk. dari tahun 2013 - 2017 yang memiliki nilai Debt To Equity yang tinggi tidak memberikan pengaruh terhadap nilai Return Saham. Hal tersebut berarti menunjukkan bahwa tinggi atau rendahnya Debt To Equity tidak mempunyai dampak buruk terhadap kinerja perusahaan, karena hal yang mempengaruhi hal tersebut lebih banyak berhubungan dengan faktor lain diluar return saham, ketidakpastian kondisi ekonomi dan rendahnya minat masyarakat akan daya beli rumah, serta sentimen dari pasar bursa itu sendiri.

Hal ini sejalan dengan penelitian Sugiarti (2015) yang menyatakan debt to equity ratio tidak berpengaruh terhadap return saham, sedangkan berbeda dengan penelitian Irman Firmansyah (2016) menyatakan debt to equity ratio berpengaruh terhadap return saham.

\section{Pengaruh Net Profit Margin terhadap Return Saham}

Hipotesis kelima yang diajukan menyatakan bahwa Net Profit Margin berpengaruh terhadap Return Saham. Hasil uji koefisien regresi Net Profit Margin pada hasil output eviews 9.0 diatas menunjukkan tingkat Prob sebesar 0,411 atau lebih besar dari $0,05(0,411<0,05)$ dan nilai t-statistic sebesar $-0,827$ atau $(-0,827>-1,992)$ dimana $\mathrm{t}$-statistic lebih kecil dari $\mathrm{t}_{\text {tabel }}$ yang artinya Net Profit Margin tidak berpengaruh signifikan terhadap Return Saham sehingga $\mathrm{H}_{5}$ ditolak. 
Terbukti pada PT. Lippo Cikarang Tbk dan PT. Roda Vivtex Tbk dari tahun 2013 - 2017 yang memiliki nilai Net Profit Margin yang tinggi tidak memberikan pengaruh terhadap nilai Return Saham. Hal tersebut berarti menunjukkan bahwa para investor masih menghindari rasiorasio keuangan yang belum memberikan kepastian laba. Sama seperti pada ROA, NPM pun belum menunjukkan kepastian laba karena laba yang tinggi belum mampu digambarkan dengan NPM yang tinggi. Jika laba yang diperoleh besar akan tetapi penjualan besar pula maka rasio NPM akan tetap kecil sehingga NPM tidak menggambarkan laba yang diperoleh. Oleh karena itu besar kecilnya NPM belum mampu memprediksi return saham syariah sehingga investor belum tertarik untuk menentukan investasinya dilihat dari rasio NPM.

Hal ini sejalan dengan penelitian Irman Firmansyah (2016) yang menyatakan net profit margintidak berpengaruh terhadap return saham, sedangkan berbeda dengan penelitian Ferdinan Eka Putra dan Paulus Kindangen (2016) yang menyatakan net profit marginberpengaruh terhadap return saham.

\section{KESIMPULAN DAN SARAN \\ Kesimpulan}

Berdasarkan hasil analisis dan pembahasan yang telah diuraikan, maka kesimpulkan dari penelitian ini sebagai berikut:

- Price Earning Ratio (PER) tidak berpengaruh signifikan terhadap Return Saham pada perusahaan properti dan real estate yang terdaftar di BEI periode 2013 - 2017. Hal ini ditunjukkan dengan nilai $t_{\text {hitung }}(1.287)<t_{\text {tabel }}$ $(1,992)$ dan nilai Prob. sebesar $0.2020>$ $\alpha$ 0,05. Dengan demikian $\mathrm{H}_{1}$ pada penelitian ini tidak terbukti.
- Earning Per Share (EPS) tidak berpengaruh signifikan terhadap Return Saham pada perusahaan properti dan real estate yang terdaftar di BEI periode 2013 - 2017. Hal ini ditunjukkan dengan nilai $t_{\text {hitung }}(-1.509)<t_{\text {tabel }}$ $(1,992)$ dan nilai Prob. sebesar $0.1355>$ $\alpha$ 0,05. Dengan demikian $\mathrm{H}_{2}$ pada penelitian ini tidak terbukti.

- Return On Equity (ROE) berpengaruh signifikan terhadap Return Saham pada perusahaan properti dan real estate yang terdaftar di BEI periode 2013 2017. Hal ini ditunjukkan dengan nilai $t_{\text {hitung }}(4.802)>t_{\text {tabel }}(1,992)$ dan nilai Prob. sebesar $0.0000<\alpha$ 0,05.Dengan demikian $\mathrm{H}_{3}$ pada penelitian ini terbukti.

- Debt to Equity Ratio (DER) tidak berpengaruh signifikan terhadap Return Saham pada perusahaan properti dan real estate yang terdaftar di BEI periode 2013 - 2017. Hal ini ditunjukkan dengan nilai $t_{\text {hitung }}(-1.406)<t_{\text {tabel }}$ $(1,992)$ dannilai Prob. sebesar $0.1638>$ $\alpha$ 0,05. Dengan demikian $\mathrm{H}_{4}$ pada penelitian ini tidak terbukti.

- Net Profit Margin (NPM) tidak berpengaruh signifikan terhadap Return Saham pada perusahaan properti dan real estate yang terdaftar di BEI periode 2013 - 2017. Hal ini ditunjukkan dengan nilai $\mathrm{t}_{\text {hitung }}(-0.826)<\mathrm{t}_{\text {tabel }}$ $(1,992)$ dan nilai Prob. sebesar $0.4110>$ $\alpha$ 0,05. Dengan demikian $\mathrm{H}_{5}$ pada penelitian ini tidak terbukti.

\section{Saran}

\section{Kontribusi Teoritis}

- Mahasiswa Jurusan Akuntansi

penelitian ini bermanfaat sebagai bahan referensi penelitian selanjutnya dan pembanding untuk menambah ilmu pengetahuan. 


\section{- Masyarakat Bisnis}

Sebagai sarana informasi tentang Return Saham dan Manajemen Keuangan dengan memberikan bukti empiris tentang Pengaruh Price Earning Ratio, Earning per Share, Return on Equity, Debt to Equity ratio dan Net Profit Margin terhadap Return Saham.

\section{- Peneliti berikutnya}

Sebagai bahan referensi bagi pihak-pihak yang akan melaksanakan penelitian lebih lanjut mengenai topik ini.

\section{- Penulis}

Sebagai sarana untuk memperluas wawasan serta menambah referensi mengenai manajemen keuangan, terutama tentang kinerja Perusahaan sehingga diharapkan dapat bermanfaat bagi penulis di masa yang akan datang.

\section{Kontribusi Praktis}

\section{- Bagi perusahaan}

Hasil penelitian ini diharapkan hasil dapat digunakan oleh perusahaan sebagai bahan pertimbangan faktor-faktor untuk meningkatkan Profitabilitas perusahaan.

\section{- Bagi Investor}

Hasil penelitian diharapkan investor dapat mengambil keputusan investasi yang lebih baik dari sisi Profitabilitas perusahaan.

\section{DAFTAR PUSTAKA}

Agnes, Sawir. 2009. Analisa Kinerja Keuangan dan Perencanaan Keuangan Perusahaan. Jakarta: PT. Gramedia Pustaka Utama.

Alwi, Z Iskandar. 2003. Pasar Modal: Teori dan Aplikasi. Jakarta: Nasindo Internusa.
Ang, Robert. 1997. Buku Pintar Pasar Modal Indonesia (The Intelligent Guide to Indonesian Capital Market). Jakarta: Mediasoft Indonesia.

Baltagi, B.H. 2008. Econometric Analysis of Panel Data. Chichester: John Wiley.

Basuki, Agus Tri dan Nano Prawoto. 2016. Analisis Regresi Dalam Penelitian Ekonomi \& Bisnis: Dilengkapi Aplikasi SPSS \& Eviews. Jakarta: PT Raja grafindo Persada.

Brigham, Eugene F. dan Joel F. Houston. 2006. Dasar-dasar Manajemen Keuangan. Jakarta: Salemba Empat.

Carlo, Michael Aldo. 2014. Pengaruh Return on equity, Dividend Payout Ratio, dan Price earning ratio Pada Return Saham. E-Jurnal Akuntansi Universitas Udayana Vol.7 No.1. ISSN: 2302-8556.

Fahmi, Irham. 2011. Analisis Laporan Keuangan. Bandung: Alfabeta.

Fahmi, Irham. 2012. Analisis Kinerja Keuangan. Bandung: Alfabeta.

Firmansyah, Irman. 2016. Determinan Return Saham Syariah Dengan Risiko Sistematis Sebagai Variabel Mediasi. Jurnal Keuangan dan Perbankan, Vol.20, No.3. Hal: 358-368. Terakreditasi SK. No. 040/P/2014. Tasikmalaya.

Gunadi, Gd Gilang dan I Ketut Wijaya Kesuma. 2015. Pengaruh ROA, DER, EPS Terhadap Return Saham Perusahaan Food and 
Beverage BEI. E-Jurnal

Manajemen Unud, Vol.4, No.6, hal: 1636-1647 ISSN: 2302-8912.

Hadi, Nor. 2013. Pasar Modal: Acuan Teoritis dan Praktis Investasi di Instrument Keuangan Pasar Modal. Yogyakarta: Graha Ilmu.

Harahap. 2007. Analisis Kritis Atas Laporan Keuangan. Jakarta: Raja Grafindo Persada.

Hartono, Jogiyanto. 2010. Teori Portofolio dan Analisis Investasi. Yogyakarta: BPFE UGM.

Horne, James C. Van dan John M. Wachowicz. 1997. Prinsipprinsip Manajemen Keuangan. Jakarta: Salemba Empat.

Legiman, Fachreza Muhammad, et al. 2015. Faktor-faktor yang Mempengaruhi Return Saham Pada Perusahaan Argoindustry yang Terdaftar di Bursa Efek Indonesia periode 2009-2012. Jurnal EMBA. Vol.3, No.3.

Maharani, Satia Nur. 2012. Kandungan Informasi Laba Bersih dan Arus Kas Terhadap Reaksi Perubahan Return Saham. Jurnal Keuangan dan Perbankan, Vol.16, No.1. Hal: 86-89. Terakreditasi SK. No. 64a/DIKTI/Kep/2010. Malang.

Martalena dan Maya Malinda. 2011. Pengantar Pasar Modal. Yogyakarta: Andi.

Martono dan Agus Harjito. 2010. Manajemen Keuangan. Yogyakarta: Ekonisia.
Nachrowi, Djalal dan Hardius Usman. 2006. Pendekatan Populer dan Praktis Ekonometrika Untuk Analisis Ekonomi dan Keuangan. Jakarta: Universitas Indonesia.

Putra, Ferdinan Eka dan Paulus Kindangen. 2016. Pengaruh Return On Asset (ROA), Net Profit Margin (NPM), dan Earning Per Share (EPS) Terhadap Return Saham Perusahaan Makanan dan Minuman yang Terdaftar di Bursa Efek Indonesia (Periode 2010-2014). Jurnal EMBA, Vol.4, No.4. Hal: 235 245. ISSN: 2303-1174. Manado.

Samsul, Mohammad. 2006. Pasar Modal dan Manajemen Portofolio. Surabaya: Erlangga.

Saputra, Dedy Oktri Hadi dan Rini Indriani. 2012. Pengaruh Rasio Analisis Fundamental

Terhadap Return Saham: Perbedaan Pengaruh Antara Saham Syariah dan Non Syariah. Jurnal Akuntansi dan Keuangan, Vol.2, No.1. Hal: 31-47. ISSN: 2301-4717. Bengkulu.

Sillaban, Anni. 2007. Analisis Faktorfaktor yang Mempengaruhi Return Saham Perusahaan Manufaktur yang Go Publik di Bursa Efek Indonesia. Jurnal Majalah Ekonomi. Vol.6, No.1. Hal: 23-35.

Sodikin, Suherman dan Nurul Wuldani. 2016. Pengaruh Price earning ratio (PER) dan Earning per share (EPS) Terhadap Return 
Saham (Studi Pada PT. Unilever Indonesia Tbk.). Jurnal Ekonomi Manajemen Vol.2 No.1 Hal. 1825 ISSN: $2477-$ 2275.

Suad, Husnan. 2005. Dasar-dasar Teori Portofolio dan Analisis Sekuritas. Yogyakarta: BPFE.

Sugiarti, Surachman dan Siti Aisjah. 2015. Pengaruh Kinerja Keuangan Perusahaan Terhadap Return Saham (Studi pada Perusahaan Manufaktur yang Terdaftar di Bursa Efek Indonesia). Jurnal Aplikasi Manajemen (JAM), Vol.13, No.2. Hal: 282-298. Terakreditasi SK. No. 66b/DIKTI/Kep/2011.

ISSN: 1693-5241. Malang.

Sugiyono. 2017. Metode Penelitian Kuantitatif, Kualitatif dan $R \& D$. Bandung: Alfabeta.

Susilowati, Yeye dan Tri Turyanto. 2011. Reaksi Signal Rasio Profitabilitas dan Rasio Solvabilitas Terhadap Return Saham Perusahaan. Jurnal Dinamika Keuangan dan Perbankan. Vol.3 No.1. hal: 1737.

Tandelilin, Eduardus. 2010. Portofolio dan Investasi Teori dan Aplikasi. Yogyakarta:

Kanisius.

Wardiyah, Mia Lasmi. 2017. Manajemen Pasar Uang \& Pasar Modal. Bandung: Pustaka Setia.

Winarno, Wing Wahyu. 2017. Analisis Ekonometrika dan Statistika dengan Eviews. Yogyakarta: STIM YKPN.
Yulianti, Eka Budi dan Suratno. 2015. Pengaruh Return on equity, Debt to equity ratio, Price earning ratio, Assets Growth, dan Inflasi terhadap Return Saham Perusahaan Properti dan Real estate. Jurnal Riset Akuntansi dan Perpajakan JRAP Vol.2, No.2, hal 153-166. ISSN 2339-1545.

www.idx.co.id (Senin, 11 Juni 2018)

www.investasi.kontan.co.id (Kamis, 19 April 2018)

www.katadata.co.id (Kamis, 19 April 2018)

www.bareksa.com (Jum'at, 20 April 2018)

www.cnnindonesia.com (Jum'at, 20 April 2018) 